\title{
Granular cell tumor (GCT) mimicking a nonsecreting anterior pituitary adenoma
}

Tumor de células granulares (TCG) mimetizando um adenoma hipofisário não produtor Denise Tieko Sasazawa', Fabiano Reis², Luciano Souza Queiroz³, Fábio Rogério³, Heraldo Mendes Garmes

A 33-year-old male with right eye amaurosis and panhypopituitarism previously submitted to surgery and radiotherapy was admitted with a presumptive recurrence of a nonsecreting pituitary macroadenoma (the first diagnosis, in another service). Magnetic Resonance Imaging (MRI) confirmed an expansive solid isointense lesion in the posterior region of the sella with suprasellar component
(Figure 1). After a new surgery, histological revealed granular cell tumor (GCT) (Figure 2).

GCT of the CNS is rare ${ }^{1}$.This report emphasizes the importance of this differential diagnosis in preoperatory for solid lesions with suprasellar component, homogeneous enhancement, and hyperattenuated on CT since they are more vascular and tend to bleed more than macroadenomas ${ }^{2}$.
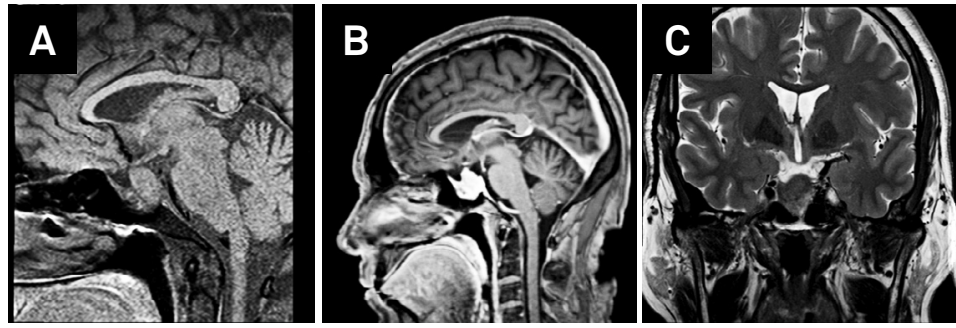

Figure 1. Sagittal T1-weighted MRI showing a circumscribed sellar/suprasellar mass (A) with homogeneous contrast enhancement (B). The lesion is predominantly hypointense on T2-weighted image (C, coronal). In all the images, there was absence of the normal pituitary bright spot.
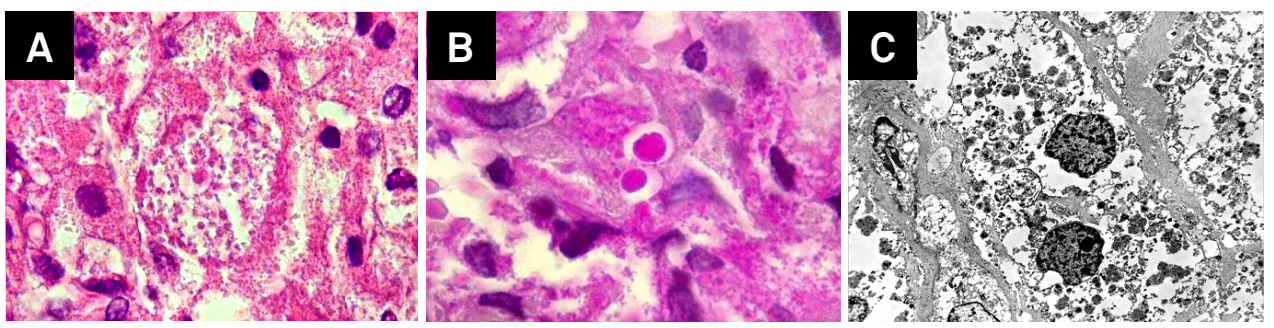

Figure 2. In the first surgical sample, the lesion showed morphological features essentially similar to those observed in the second specimen. Cells with cytoplasmic granules (A; Hematoxylin-eosin), which do not contain glycogen (B; Periodic Acid-Schiff with diastase digestion) and correspond to lysossomes (C: electron microscopy). In the first surgical sample, the lesion showed morphological features essentially similar to those observed in the second specimen.

1. Covington MF, Chin SS, Osborn AG. Pituicytoma, spindle cell oncocytoma, and granular cell tumor: clarification and meta-analysis of the world literature since 1893. Am J Neuroradiol. 2011;32(11):2067-72. doi:10.3174/ajnr.A2717
2. Aquilina K, Kamel M, Kalimuthu SG, Marks JC, Keohane C. Granular cell tumour of the neurohypophysis: a rare sellar tumour with specific radiological and operative features. Br $\mathrm{J}$ Neurosurg. 2006;20(1):51-4. doi:10.1080/02688690600600996

'Universidade Estadual de Campinas, Faculdade de Ciências Médicas, Disciplina de Endocrinologia , Departamento de Clínica Médica, Campinas SP, Brazil; 2Universidade Estadual de Campinas, Faculdade de Ciências Médicas, Departamento de Radiologia, Campinas SP, Brazil;

${ }^{3}$ Universidade Estadual de Campinas, Faculdade de Ciências Médicas, Departamento de Patologia, Campinas SP, Brazil.

Correspondence: Denise Tieko Sasazawa; Departamento de Clínica Médica - UNICAMP; Rua Tessália Vieira Camargo, 126; Cidade Universitária Zeferino Vaz; 13083-887 Campinas SP, Brasil; E-mail: denisesasazawa@gmail.com

Conflict of interest: There is no conflict of interest to declare.

Received 10 April 2015; Received in final form 05 June 2015; Accepted 25 June 2015. 